\title{
MODIFIKASI SISTEM PENGELOLAAN KAWASAN MANGROVE DAN AREA ARTIFICIAL CORAL SEBAGAI LABORATORIUM ALAM DI KAMPUS EKOWISATA LAUT TATELI (MODIFICATION OF MANGROVE AREA AND ARTIFICIAL CORAL AREA MANAGEMENT SYSTEM AS A NATURAL LABORATORY AT TATELI MARINE ECO- TOURISM CAMPUS)
}

\author{
Easter Tulung` Dannie R. S. Oroh, Frans V. Rattu, Alma Pongtuluran \\ Program Studi Ekowisata Laut, Politeknik Negeri Manado \\ *E-mail: easter_tulung@gmail.com
}

\begin{abstract}
The research, which was conducted in the Coral and Mangrove Modulation Area, Tateli Campus, Manado State Polytechnic, from January to October 2020, aimed to obtain data on the growth of mangroves in the Coral \& Mangrove Modulation Area of the Tateli Campus. nature and research place for lecturers. Collecting data using a mangrove modulation area of $20 \mathrm{~m} 2$ and divided into four quadrants measuring $10 \mathrm{~m} 2$. Observations and data collection in this study included measurements of trees, saplings, seedling height, seedling leaves, and seedlings branches. As for Coral Reefs using the observation method. Observation is conducting direct observations in the field to dive and take pictures and measure the growth of corals in that location. Observations were made every month, by measuring the length of the transplanted coral using a ruler to determine coral growth. Furthermore, coral length growth data were analyzed using Microsoft Excel. From this research, it can be concluded that the existing mangrove areas and artificial coral areas are identified as very suitable to be used as natural laboratories for learning and research at the Tateli Marine Ecotourism Campus. There were several individual mangroves whose growth was observed, which was seen from the height, number of leaves and mangrove branches. Ecological and oceanographic conditions of mangrove ecosystems are temperature, salinity, $\mathrm{pH}$, depth and brightness which are very good for the suitability of mangrove ecosystems and coral reefs as a natural laboratory because the measurement results show numbers that are still within the quality standard limits according to the Quality Standard of Minister of Environment Decree No. 51 of 2004.
\end{abstract}

Keywords: mangrove ecosystem, coral reefs, ecological conditions, growth, natural laboratory, ecotourism

Penelitian yang dilaksanakan di Area Modulasi Karang dan Mangrove Kampus Tateli Politeknik Negeri Manado, pada bulan Januari sampai Oktober tahun 2020 ini bertujuan mendapatkan data pertumbuhan mangrove yang berada di Area Modulasi Karang \& Mangrove Kampus Tateli kemudian diatur dan dikembangkan untuk menjadi sarana pembelajaran mahasiswa atau sebagai laboratorium alam dan tempat penelitian bagi dosen. Pengambilan data dengan menggunakan luasan modulasi mangrove seluas $20 \mathrm{~m}^{2}$ dan dibagi menjadi empat kuadran berukuran $10 \mathrm{~m}^{2}$, Pengamatan dan pengumpulan data dalam penelitian ini meliputi pengukuran pohon, pancang, tinggi semai, daun semai, dan cabang semai. Sedangkan untuk Terumbu Karang menggunakan metode observasi. Observasi adalah mengadakan pengamatan secara langsung di lapangan untuk melakuakan penyelaman dan pengambilan gambar serta mengukur pertumbuhan karang yang ada di lokasi tersebut. Pengamatan dilakukan setiap bulan, dengan cara mengukur panjang karang yang ditransplantasi menggunakan mistar untuk mengetahui pertumbuhan karang. Selanjutnya data pertumbuhan panjang karang dianalisis menggunakan bantuan Microsoft Excel. Dari penelitian ini dapat disimpulkan bahwa daerah mangrove dan area artificial coral yang ada, teridentifikasi sangat layak untuk dijadikan laboratorium alam untuk pembelajaran dan penelitian di Kampus Ekowisata Laut Tateli. Ada beberapa individu mangrove yang di amati pertumbuhannya, yang dilihat dari tinggi, jumlah daun dan cabang mangrove. Kondisi ekologi dan oseanografi ekosistem mangrove adalah suhu, salinitas, $\mathrm{pH}$, kedalaman dan kecerahan sangat baik untuk kesesuaian lahan ekosistem mangrove dan terumbu karang sebagai laboratorium alam karena hasil pengukuran menunjukkan angka yang masih masuk dalam batas baku mutu sesuai dengan Baku Mutu Kepmen LH No. 51 Tahun 2004.

Kata kunci: Ekosistem mangrove, terumbu karang, kondisi ekologis, pertumbuhan, labarotorium alam, ekowisata 


\section{PENDAHULUAN}

Lingkungan dapat dimanfaatkan pembelajaran mata kuliah sains. Lingkungan yang merupakan sasaran, sumber dan sarana belajar dapat digunakan sebagai tempat untuk melakukan praktek, demonstrasi, percobaan, penelitian, dan pengambilan ilmu pengetahuan dalam proses pembelajaran. Dengan memanfaatkan lingkungan sebagai laboratorium alam dalam proses pembelajaran diharapkan mahasiswa akan memperoleh informasi berdasarkan pengalaman langsung dan bisa belajar dari hal-hal yang bersifat konkret sehingga anak didik akan lebih mudah memahami materi dan pembelajaran yang dialami lebih bermakna.

Kampus Tateli merupakan tempat pembelajaran mahasiswa Politeknik Negeri Manado khususnya mahasiswa Jurusan Pariwisata Program Studi Ekowisata Bawah Laut. Selain tempat kuliah, dimana mahasiswa bertatap muka dengan dosen, juga dikampus inilah direncanakan untuk adanya pengembangan kawasan Mangrove dan area artificial coral sebagai laboratorium alam untuk pelaksanaan praktek bagi mahasiswa. Adanya pengembangan laboratorium alam dimaksudkan untuk efesiensi dan efektifitas, sehingga pelaksanaan praktek tidak akan dibatasi oleh waktu dan biaya. sehingga mahasiswa yang adalah pokok pembelajaran mendapatkan hak penuh dalam hal praktek, mengingat Politeknik merupakan institusi pendidikan tinggi atau pendidikan vokasi profesional yang menempatkan praktek di angka $60 \%$ dan teori $40 \%$.

Kawasan Mangrove dan area artificial Coral sejak tahun 2018 dikembangkan dalam penelitian dosen, dengan menitikberatkan pada Modulasi Mangrove sedangkan artificial Coral dalam bentuk transplantasi model rak yang berguna juga untuk area perlindungan laut di Perairan Tateli II. Selain sebagai sarana pembelajaran dengan hadirnya laboratorium alam dikampus ekowsiata laut juga sebagai daerah perlindungan laut yang adalah bagian dari koservasi di kawasan pesisir. linilah yang menjadi sentral penelitian dari Program Studi Ekowisata Laut ditahun ini. Dengan adanya penelitian ini, maka pengembangan laboratorium alam di Kampus Ekowisata Laut akan terealisasi sehingga apa yang menjadi visi dan misi Prodi akan tercapai.

\section{Tujuan}

1. Menginvestigasi kondisi ekologi dan oseanografi ekosistem mangrove dan menganalisa kesesuaian lahan ekosistem mangrove sebagai laboratorium alam.

2. Mendapatkan data perkembangan ekosistem terumbu karang untuk dan mangrove

3. Mengkomparasi data mangrove dan terumbu karang dan memodifikasi sistem area mangrove dan terumbu karang buatan sebagai sarana edukasi

\section{METODOLOGI PENELITIAN}

Dengan mengambil lokasi di Kampus Ekowisata Laut yang dikenal dengan Kampus B, terletak di Desa Tateli II Kecamatan Mandolang Kabupaten Minahasa. Dan Waktu pelaksanaan adalah Maret 2020 sampai Desember 2020 


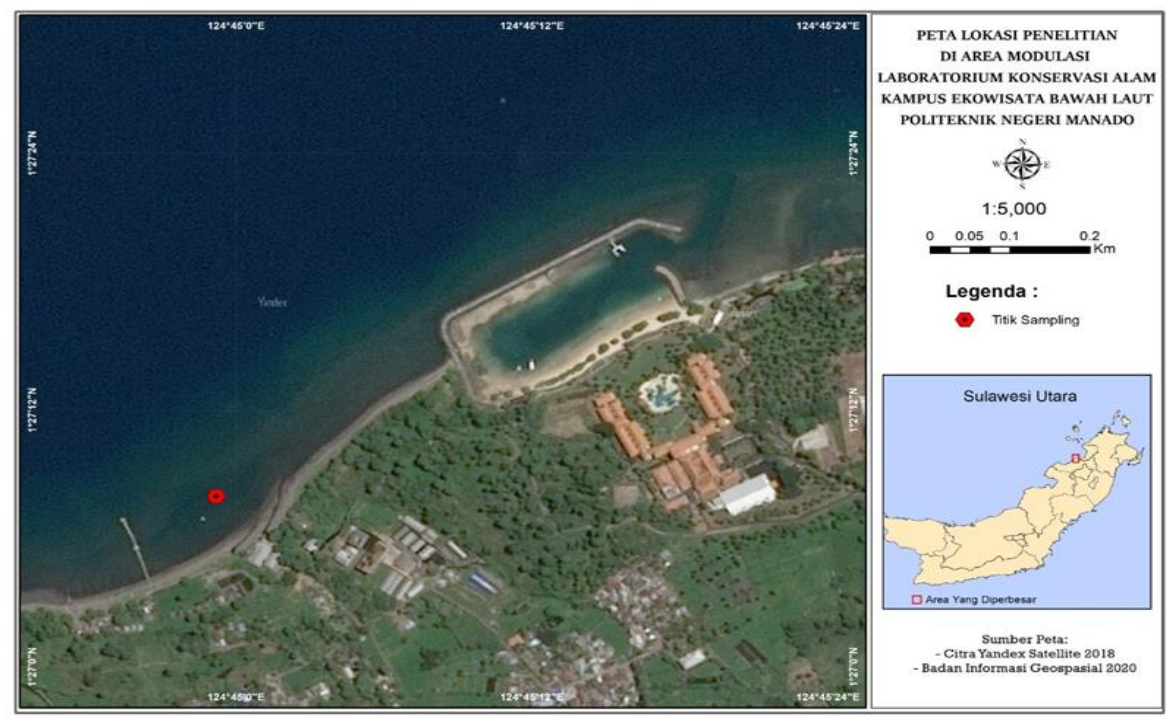

Gambar 1. Peta dan Foto Kawasan Pesisir Tateli

Metode Penelitan ini dilakukan secara bertahap yaitu koordinasi instansi terkait dan sosialisasi masyarakat, survei detail kondisi hidro-oseanografi calon lokasi penurunan terumbu, konstruksi terumbu buatan serta penanaman terumbu pada lokasi terpilih. Kemudian survey ekologis yang dilakukan pada ekosistem mangrove yang ada baik itu hasil penelitian pada tahun 2019 tentang Mangrove dan Terumbu Karang disepanjang Teluk Manado sebagai Destinasi Wisata Baru juga tentang hasil kajian Modulasi Mangfrove di Kampus B Tateli.

Data dalam penelitian ini adalah: data primer diperoleh dari monitoring dan observasi lapangan dan wawancara secara langsung dan data sekunder yaiutu data yang telah lebih dulu dikumpulkan dan dilaporkan oleh orang atau instansi diluar diri peneliti sendiri, walaupun data yang dikumpulkan itu sebenarnya data yang asli.

Penentuan lokasi penempatan terumbu buatan yang akan dijadikan sebagai rumah ikan disesuaikan dengan dengan kondisi lingkungan yang memungkinkan organisme penempel sebagai cikal bakal tumbuhnya terumbu buatan bisa tumbuh cepat dan area artificial coral yang akan dijadikan sebagai laboratorium alam di Kampus Ekowisata Laut Tateli. dengan memperhatikan faktor-faktor pendukung untuk tumbuhnya terumbu karang alami (suhu, salinitas, kedalaman, kecerahan, tubiditas, sedimentasi dan arus) serta stabilisasi dan daya tahan terumbu buatan yang ditempatkan. Untuk mendukung keberhasilan program penanaman terumbu buatan ini perlu pengamatan: $f$ Kajian sosial ekonomi masyarakat setempat, Kajian geologi dasar laut (batimetri, karakteristik dasar laut dan substrat dasar). Peralatan yang digunakan adalah fish finder, computer, GPS dan Sedimen grab. $f$ Kajian oseanografi (arus) dan kualitas air laut (suhu, salinitas, $\mathrm{pH}$, kecerahan, turbidity). Peralatan yang digunakan current meter, water quality checker.

Kemudian dilakukan penelitian pada lokasi daerah mangrove, pertama dengan melihat factor atau dari segi ekologi kemudian dari segi oseanografi, dari sini akan diperoleh data awal dan informasi untuk penentuan struktur Artificial Reef dan area Mangrove di sepanjang Teluk Manado. Data-data yang ada akan dipakai dalam rangka untuk pengelolaan system di Kawasan mangrove 


\section{HASIL DAN PEMBAHASAN}

\section{A. Terumbu Karang}

Dalam penelitian ini genus karang yang diukur pertumbuhannya dalam modul transpaltasi Polimdo dan bentuk kotak di area Laboratorium Alam Kampus Ekowisata Bawah
Laut Politeknik Negeri Manado adalah genus Acropora dan Pocilopora. Genus Acropora memiliki beberapa variasi bentuk percabangan secara umum yaitu korimbosa, arboresen, kapitosa dan lain-lain dengan ciri khas adanya axial koralit dan radial koralit. Bentuk radial koralit juga memiliki beberapa variasi bentuk seperti tubular nariform dan lain-lain.

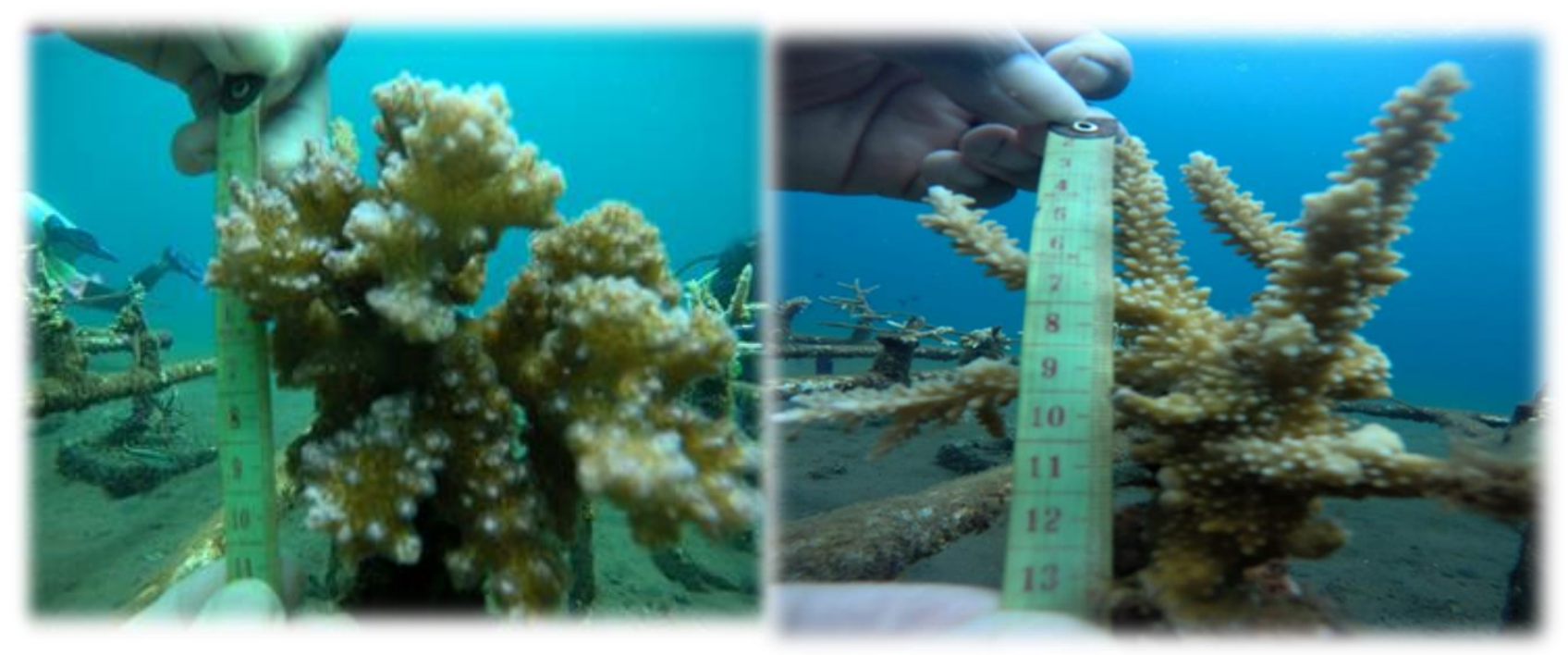

Gambar 2. Pengukuran Pertumbuhuan genus karang Acropora

Pada saat pengamatan pertama di bulan September 2019, didapatkan kondisi rata-rata panjang karang (Gambar 3) di modul polindo adalah $7,46 \mathrm{~cm}$ dari 13 fragmen karang, sedangkan pada modul kotak, kondisi rata-rata panjang karang adalah 7, 58 dari 31 fragmen karang.

Selang sepuluh bulan dilakukan pengamatan kembali terhadap panjang karang yang ada di modul Polindo dan modul Kotak, dan didapatkan rata-rata panjang karang (Gambar 1) pada modul Polindo adalah $18.33 \mathrm{~cm}$ dari 13 fragmen karang, sedangkan pada modul Kotak adalah $13,33 \mathrm{~cm}$.

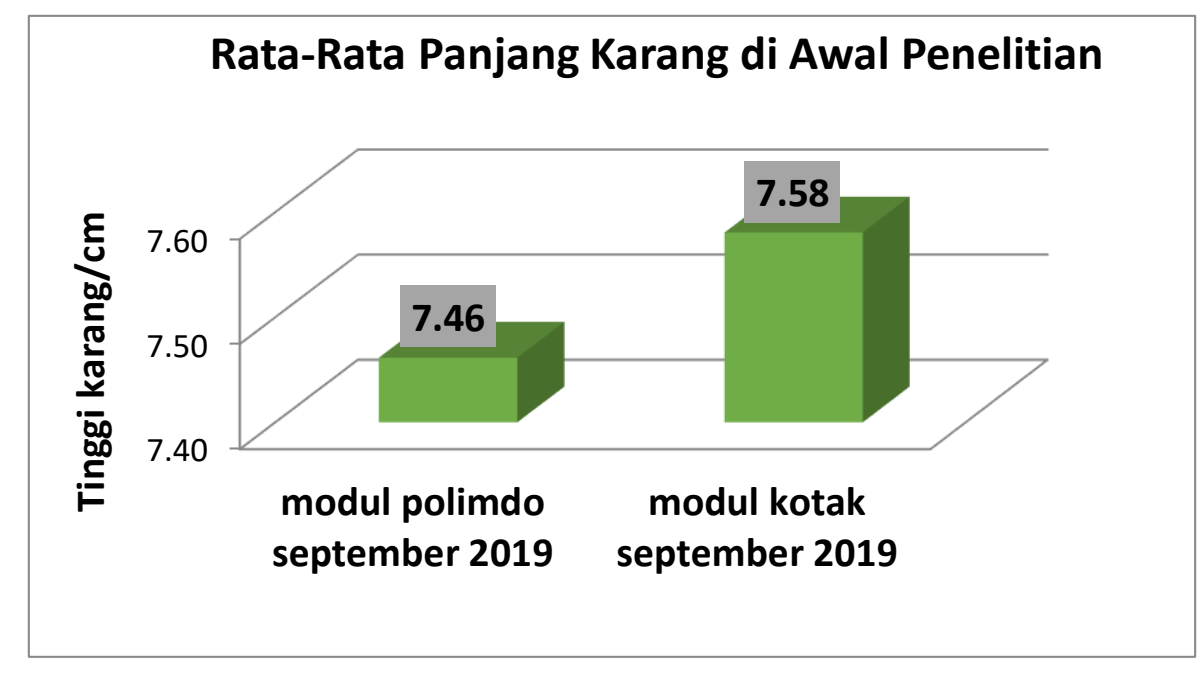

Gambar 3. Rata-rata Panjang Karang Setelah 10 Bulan 
Jika melihat kondisi rata-rata panjang karang saat pengamatan pertama di bulan September 2019 dan dibandingkan dengan kondisi panjang karang di bulan juni 2020, terlihat terjadinya pertumbuhan sehingga terjadi kenaikan rata-rata panjang karang (Gambar 4)

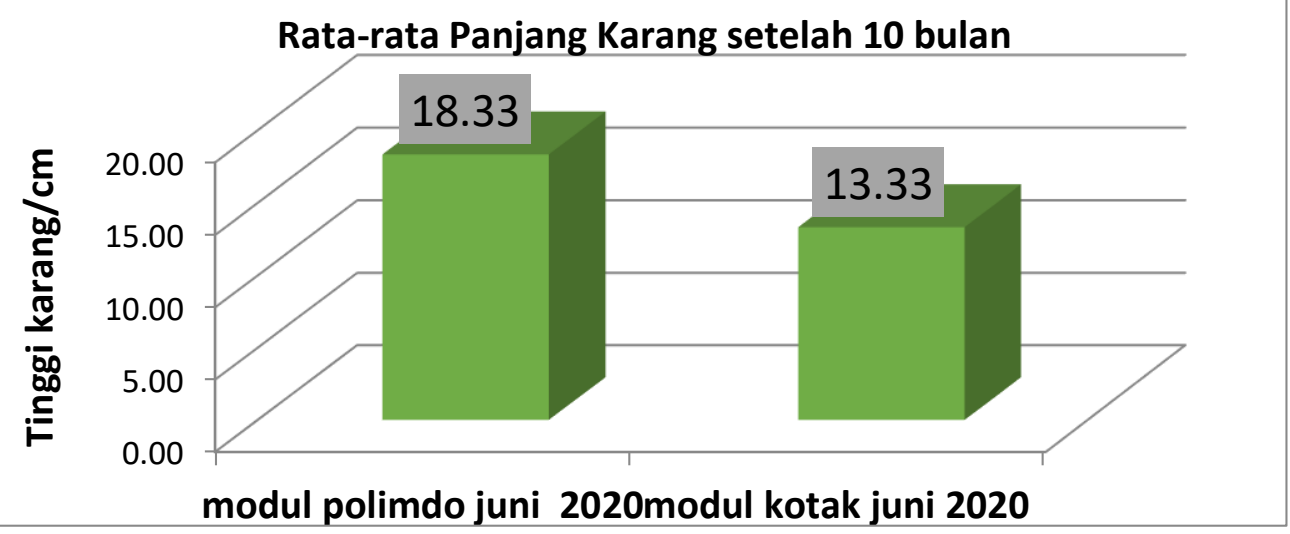

Gambar 4. Rata-rata panjang karang setelah 10 bulan

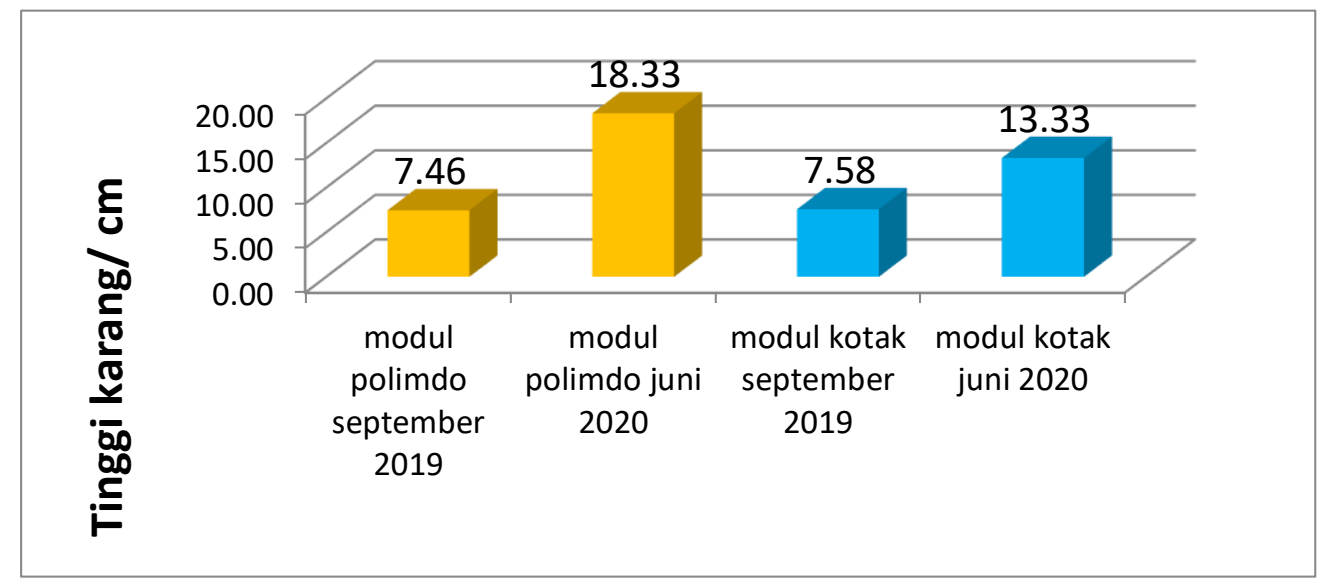

Gambar 5. Pertumbuhan Karang

\section{Pertumbuhan Karang}

Setelah melakukan analisis data yang mengacu pada (Runtuwene, et al 2020) dengan penerapan pada panjang karang untuk mengetahui pertumbuhan karang (Gambar 5) selama sepuluh (10) bulan, didapatkan bahwa pada modul polimdo pertumbuhan karang adalah $1,09 \mathrm{~cm} / \mathrm{bulan}$ sedangkan dimodul kotak adalah $0,57 \mathrm{~cm} /$ bulan). 


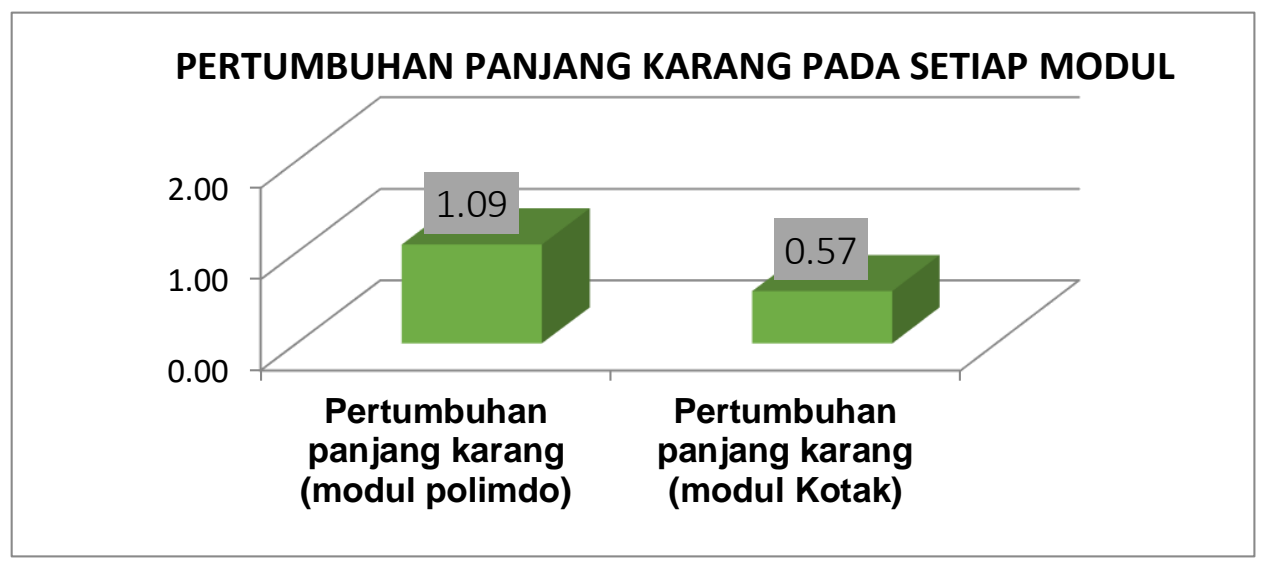

Gambar 6. Pertumbuhan Karang (perbulan)

Kegiatan transplantasi ini dikatakan berhasil karena fragmen karang yang ditransplantasi mengalami pertumbuhan dengan baik. Suhu yang relatif konstan sangat baik untuk pertumbuhan. Hal yang sama juga pada salinitas, $\mathrm{pH}$. Selain parameter lingkungan yang mendukung, lokasi peletakkan modul transplantasi pada kedalaman 4-8 $\mathrm{m}$.

Tabel 1. Hasil Pengukuran Kualitas Perairan Pantai Tateli

\begin{tabular}{|l|l|l|}
\hline $\begin{array}{l}\text { Parameter Kualitas } \\
\text { Air }\end{array}$ & $\begin{array}{l}\text { Kisaran Hasil } \\
\text { Pengukuran }\end{array}$ & $\begin{array}{l}\text { Baku Mutu Kepmen } \\
\text { LH No. 51,2004 }\end{array}$ \\
\hline Suhu & $29-31^{\circ} \mathrm{C}$ & $28-30{ }^{\circ} \mathrm{C}$ \\
\hline Salinitas & $28-29 \mathrm{ppt}$ & $23-35 \mathrm{ppt}$ \\
\hline $\mathrm{pH}$ & 7.35 & $7-8,5$ \\
\hline Kedalaman & $4-8 \mathrm{~m}$ & $<20$ \\
\hline Kecerahan & $8-9$ & $>5$ \\
\hline
\end{tabular}

Penelitian lain tentang laju pertumbuhan karang Acropora telah dilakukan sebelumnya oleh Iswara (2010) di Pulau Kelapa dengan pengamatan selama enam bulan memperoleh nilai laju pertumbuhan 0.85 cm/bulan. Sedangkan Tioho (2013) di perairan Kalasey dengan pengamatan satu tahun memperoleh nilai laju pertumbuhan pada kisaran antara $0.81-0.94 \mathrm{~cm} /$ bulan dan Mompala dkk (2017) di perairan Kareko selama empat bulan sebesar 0,96 cm/bulan.

\section{B. Mangrove}

Dari modulasi mangrove yang ada, di dapatkan empat kuadran pengamatan mangrove. Ada beberapa individu mangrove yang diamati pertumbuhannya, dilihat dari tinggi, jumlah daun dan cabang mangrove.
Pengamatan yang sudah dilakukan didapatkan hasil bahwa jenis mangrove yang ditemukan di area modulasi adalah Rhizophora apiculata, Rhizophora mucronata, Bruguiera gymnorhiza, Sonneratia alba. 

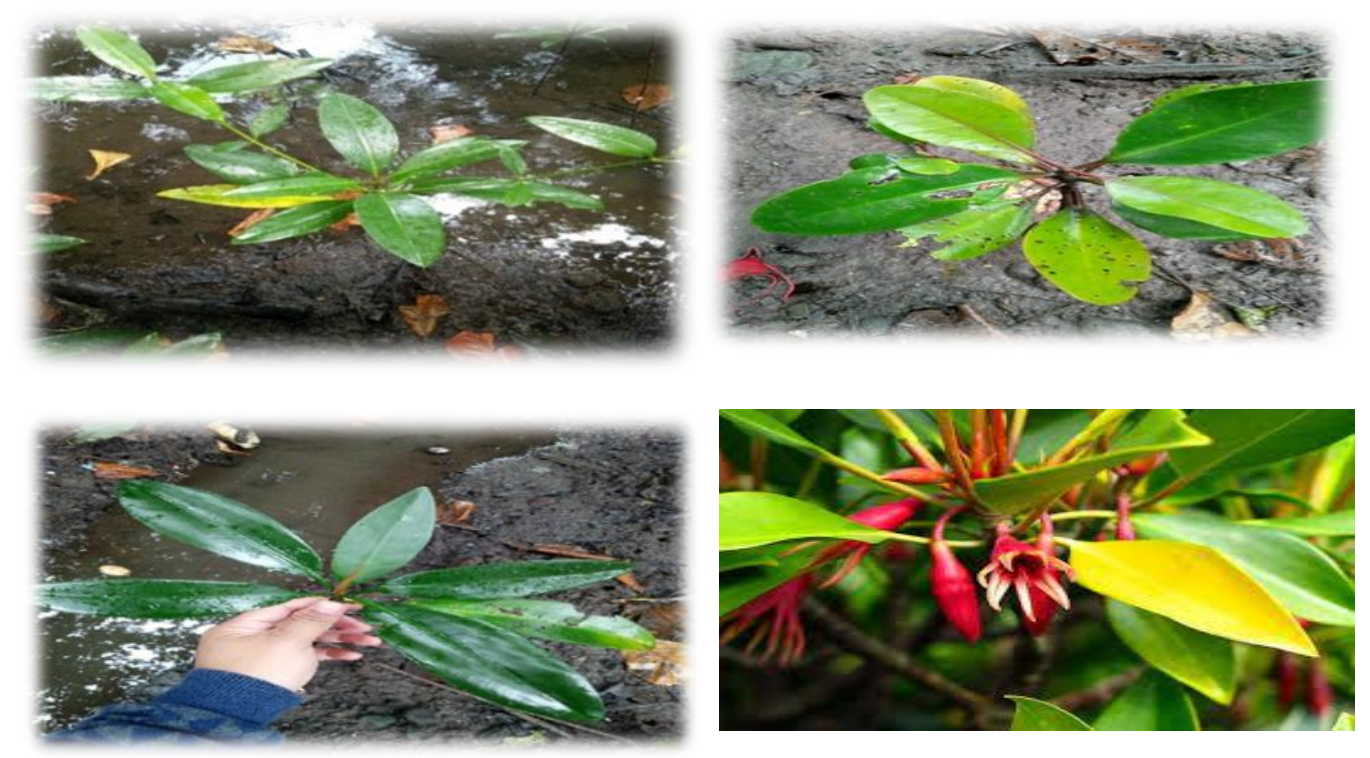

Gambar 7. Jenis Mangove yang teridentifikasi (Rhizophora apiculata, Rhizophora mucronata, Bruguiera gymnorhiza, Sonneratia alba)

\section{DESKRIPSI KUADRAN MANGROVE}

Pada kuadran satu didapatkan dua jenis mangrove dalam fase semai yaitu Rhizophora apiculate dengan 14 jumlah individu dan Rhizophora mucronata dengan 3 jumlah individu, sehinga pada kuadran ini terdapat 17 total individu mangrove. Saat dilakukan pengukuran total tinggi, total daun dan total cabang (Gambar 7) pada setiap individu mangrove yang ada, didapatkan bahwa total pertumbuhan pada mangrove jenis Rhizophora apiculata adalah sebagai berikut, total tinggi $1441 \mathrm{~cm}, 105$ helai daun, dan 54 cabang sedangan pertumbuhan pada Rhizophora mucronata didapatkan total tinggi 229, total helai daun 38 dan total cabang ada 2 , bila dibandikan dengan data di tahun sebelumnya, maka bisa dilihat terjadinya peningkatan atau pertumbuhan pada total tinggi dan total cabang, dimana untuk total pertumbuhan jenis Rhizophora apiculata pada tahun 2019 adalah total tinggi 843, total daun 171 , total cabang 0 , maka dapat dilihat terjadi pertumbuhan pada tinggi sebesar $598 \mathrm{~cm}$ dan bertambahnya cabang sebanyak 54 cabang, walaupun terjadi pengurangn daun sebnyak 66 helai, namun daun yang berkurang ini karena diduga gugur dari phon dan menjadi serasa yang selanjutnya akan menjadi suplai nutrisi pada mangrove. Bila melihat pertumbuhan Rhizophora mucronata pada 2019 dengan total tinggi 203 , total daun 21, total cabang 0 , maka bila dibandingkan dengan data di tahun 2020 didapatkan kenaikan atau pertumbuhan tinggi pohon $26 \mathrm{~cm}$, pertambahan daun sebanyak 17 helai dan pertambahan 2 cabang. 


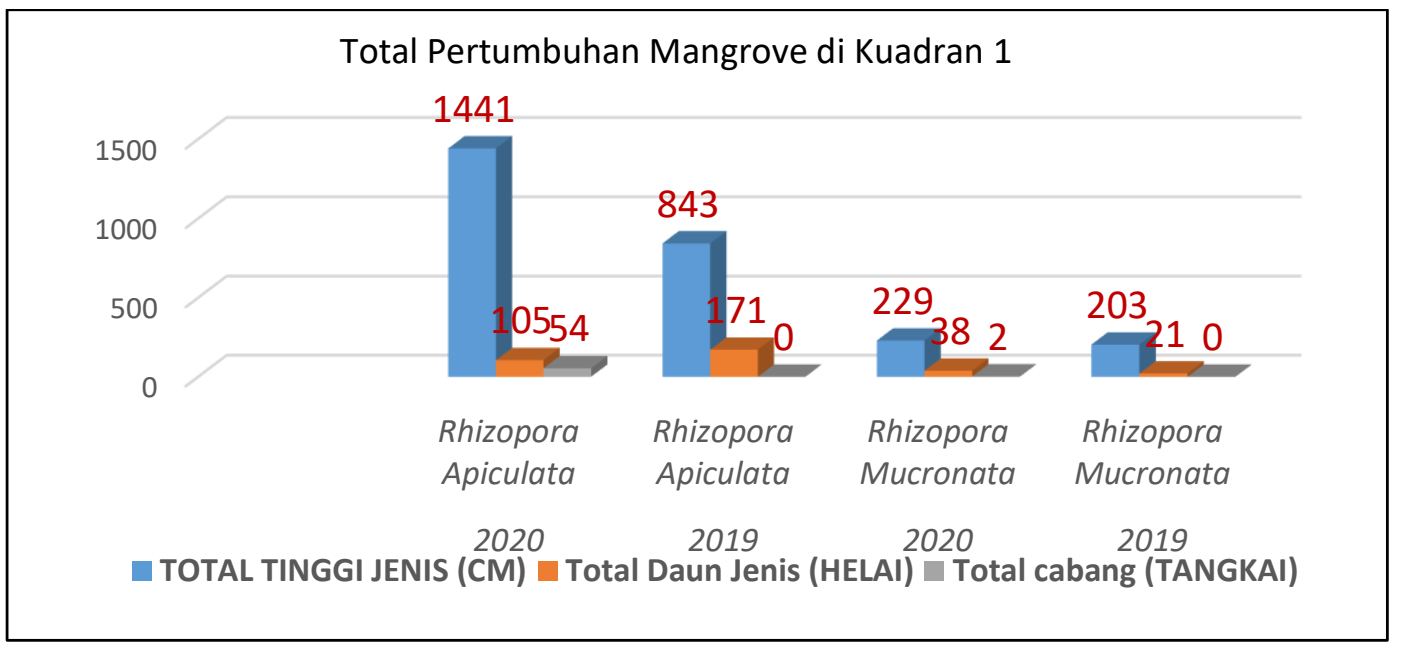

Gambar 8. Total Pertumbuhan Mangrove Pada Kuadran 1

Pada kuadran satu di dapatkan ratarata pertumbuhan (Gambar 8) dari Rhizophora Apiculata adalah rata-rata tinggi $102.93 \mathrm{~cm}$, rata-rata daun 7.50 helai dan rata-rata cabang
3 sedangkan untuk Rhizophora Mucronatarata-rata tinggi $76.33 \mathrm{~cm}$, rata-rata daun adalah 12,67 dan rata-rata cabang adalah 0,67 .

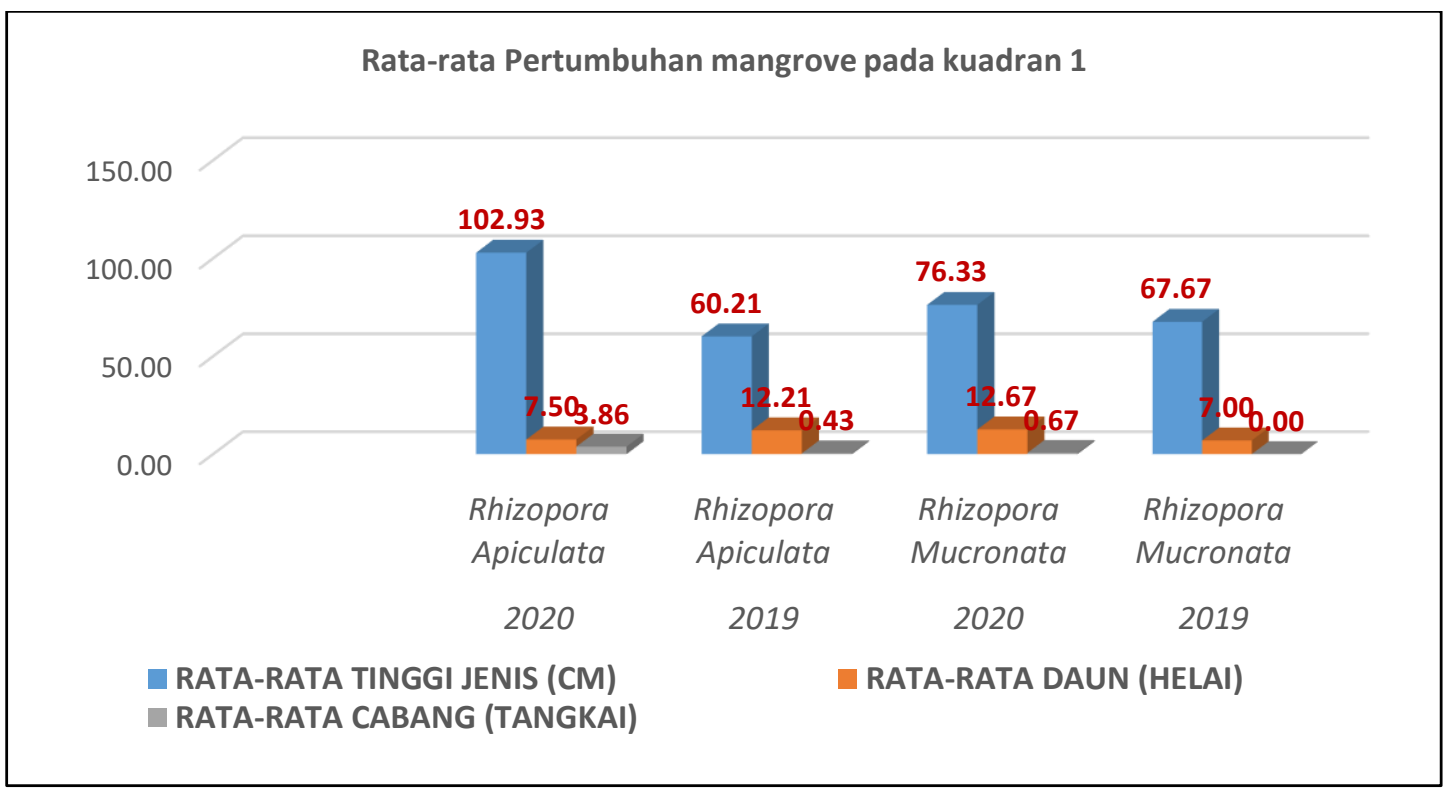

Gambar 9. Rata-rata Pertumbuhan Mangrove Pada Kuadran 1

\section{Kuadran Dua}

Pada kuadran dua didapatkan dua jenis mangrove dalam fase semai yaitu Sonneratia Alba dengan 14 jumlah individu dan Rhizophora apiculata dengan 1 jumlah individu, sehinga pada kuadran ini terdapat 15 total individu mangrove. Saat dilakukan pengukuran total tinggi, total daun dan total cabang (Gambar 9) pada setiap individu mangrove yang ada, didapatkan bahwa total pertumbuhan pada mangrove jenis Sonneratia alba adalah sebagai berikut, total tinggi 832 
cm, 147 helai daun, dan 3 cabang sedangan pertumbuhan pada Rhizophora apiculata didapatkan total tinggi $144 \mathrm{~cm}$, total helai daun 11 dan total cabang ada 1, bila dibandikan dengan data di tahun sebelumnya, maka bisa dilihat terjadinya peningkatan atau pertumbuhan pada total tinggi dan total cabang, dimana untuk total pertumbuhan jenis Sonneratia alba pada tahun 2019 adalah total tinggi $360 \mathrm{~cm}$, total daun 117 helai, total cabang 2. Maka terjadi pertumbuhan pada tinggi sepanjang $472 \mathrm{~cm}$, pada daun bertambah 30 helai dan pada cabang bertambah 1 cabang. Bila melihat pertumbuhan Rhizophora apiculata pada 2019 dengan total tinggi 78, total daun 7 helai, total cabang 0 , maka bila dibandingkan dengan data di tahun 2020 didapatkan kenaikan atau pertumbuhan tinggi pohon $66 \mathrm{~cm}$, pertambahan daun sebanyak 4 helai dan pertambahan 1 cabang.

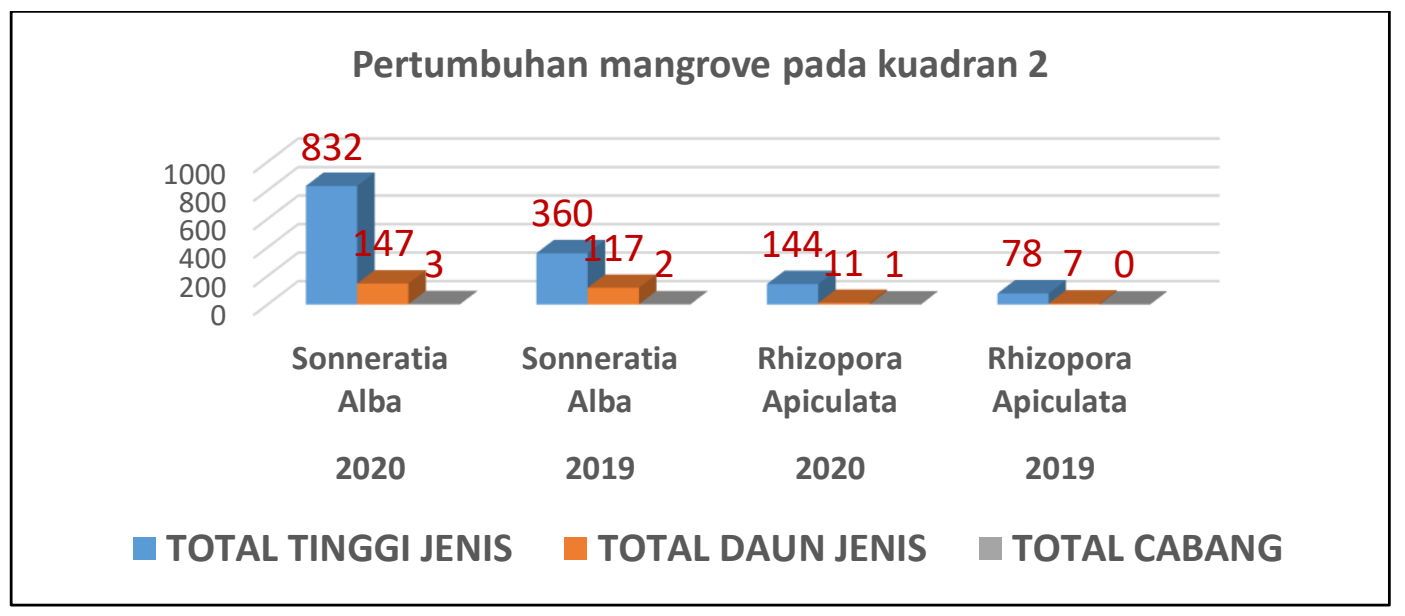

Gambar 10. Total Pertumbuhan Mangrove Pada Kuadran 2

Pada kuadran dua di dapatkan rata-rata pertumbuhan (Gambar 10) dari Sonneratia alba adalah rata-rata tinggi $59.43 \mathrm{~cm}$, rata-rata daun 10.50 helai dan rata-rata cabang 0.21 sedangkan untuk Rhizophora apiculata rata-rata tinggi $144 \mathrm{~cm}$, rata-rata daun adalah 11 helai daun-daun rata-rata cabang adalah 1. 


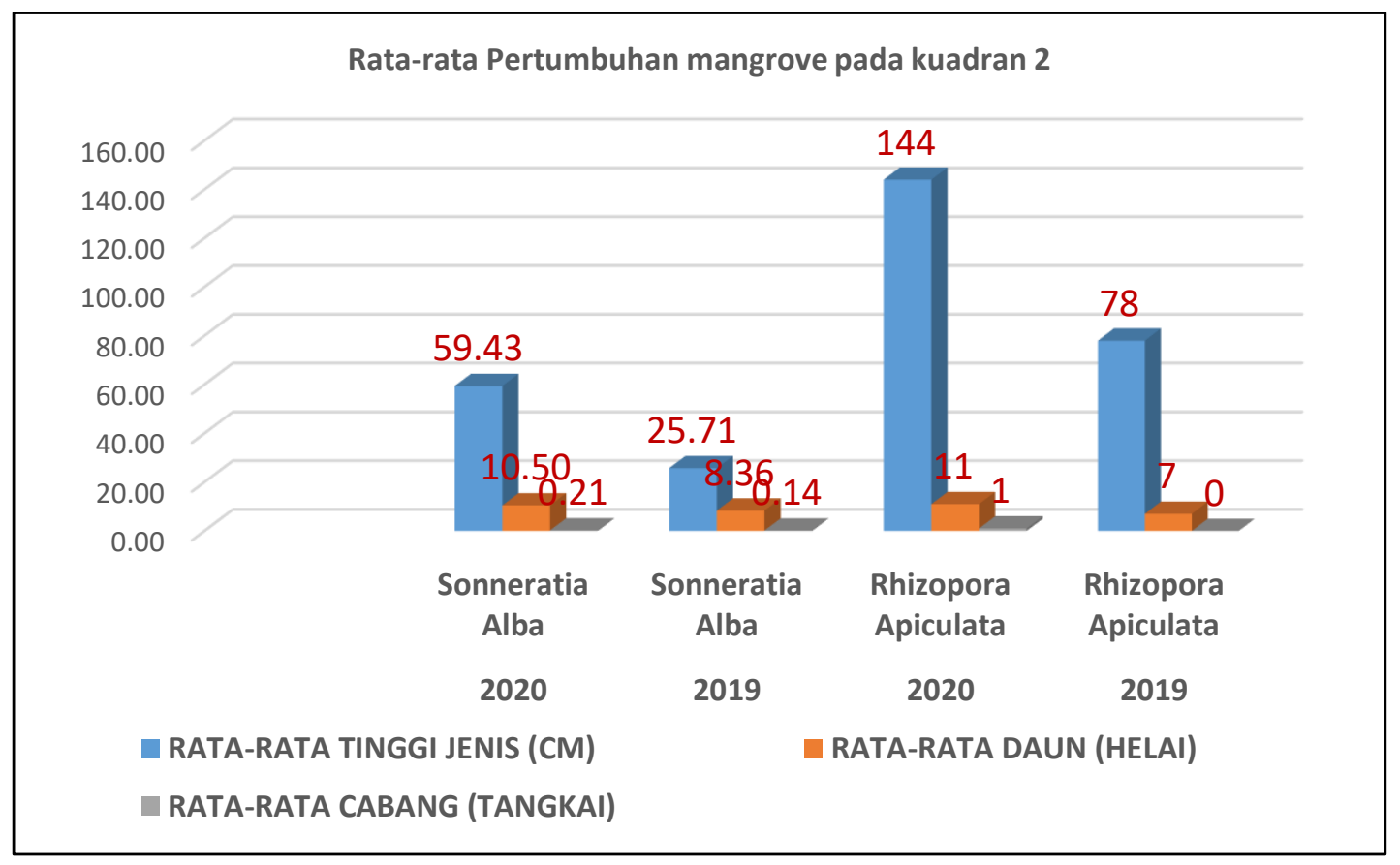

Gambar 11. Rata-rata Pertumbuhan Mangrove Pada Kuadran 2

\section{Kuadran ke Tiga}

Pada kuadran tiga hanya ditemukan satu jenis mangrove yaitu, jenis Sonneratia alba dengan 15 jumlah individu. Saat dilakukan pengukuran total tinggi, total daun dan total cabang (Gambar 11) pada setiap individu mangrove yang ada pada kuadran 3 , didapatkan bahwa total pertumbuhan pada mangrove jenis Sonneratia alba adalah sebagai berikut, total tinggi $987 \mathrm{~cm}, 236$ helai daun, dan 11 cabang. Bila melihat dari data yang ada pada tahun 2019 pada kuadran 3 ini didapatkan total tinggi $425 \mathrm{~cm}$, total daun 117 helai daun, dan hanya ditemukan 4 total cabang. Jika data di tahun 2019 dibandingkan dengan data pengukuran ditahun 2020 didapatkan perkembangan atau pertumbuhan mangrove dengan jumlah pertumbuhan 562 $\mathrm{cm}$ total tinggi, 119 total daun, dan 7 total cabang yang bertumbuh dalam satu tahun.

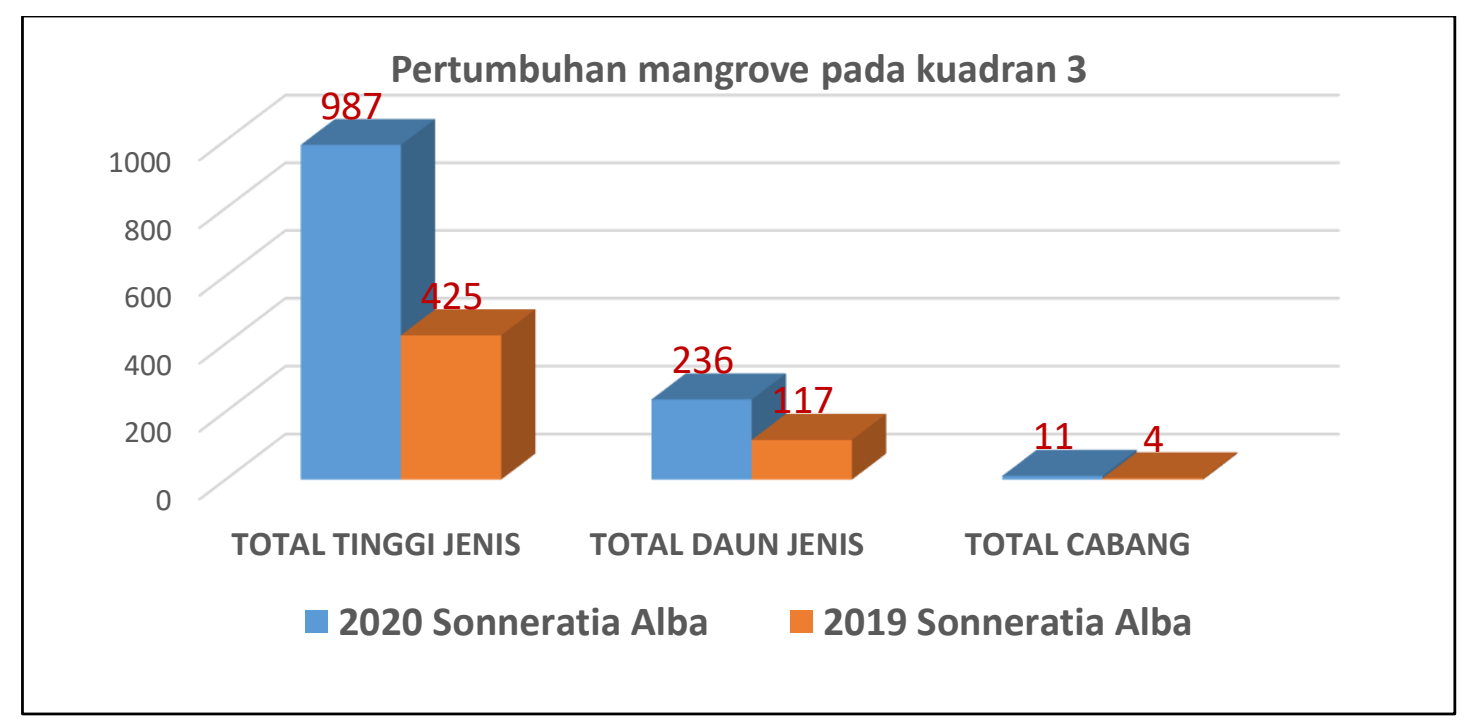

Gambar 12. Total Pertumbuhan Mangrove Pada Kuadran 3 
Pada kuadran tiga di dapatkan ratarata pertumbuhan mangrove (Gambar 12) dari Sonneratia Alba adalah rata-rata tinggi 65.80 $\mathrm{cm}$, rata-rata daun 15.73 helai dan rata-rata cabang 0.73 untuk ditahun 2020, sedangkan pada data di tahun 2019 rata-rata pertumbuhan mangrove adalah $28,33 \mathrm{~cm}$ untuk rata-rata tinggi pohon, 7.80 untuk ratarata pertumbuhan daun, 0,27 untuk rata-rata cabang

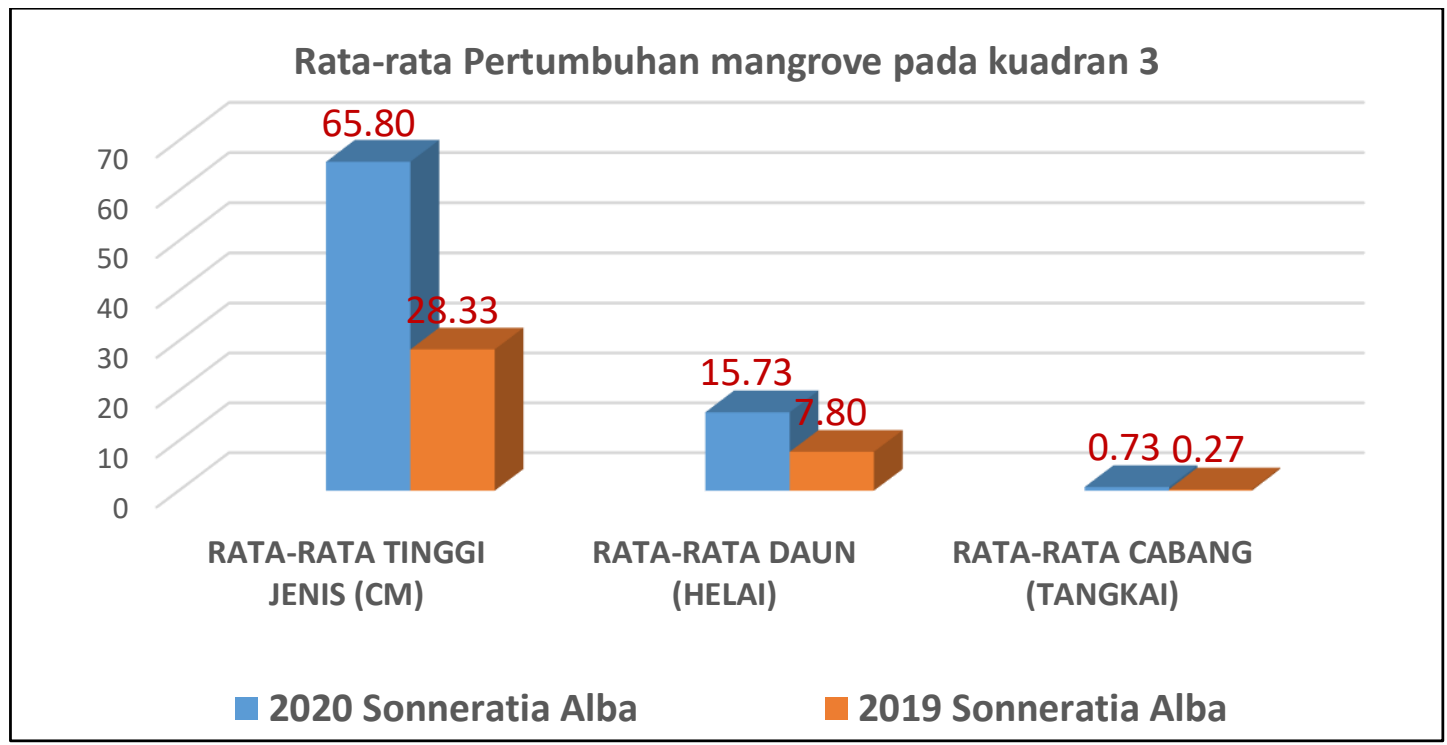

Gambar 13. Rata-rata Pertumbuhan Mangrove Pada Kuadran 3

\section{Kuadran ke Empat}

Pada kuadran ke empat didapatkan empat jenis mangrove fase semai yaitu Rhizophora apiculata Rhizophora mucronata, Brugueira gymnoriza, dan Sonneratia alba. Didalam kuadran ini didapatkan 30 individu mangrove fase semai dengan rincian 8 individu Rhizophora apiculata, 12 individu Brugueira gymnoriza, 6 individu Sonneratia alba dan 4 individu Rhizophora mucronata.Saat dilakukan pengukuran total tinggi, total daun dan total cabang (Tabel 6) pada setiap individu mangrove yang ada, didapatkan bahwa total pertumbuhan pada mangrove jenis Rhizophora Apiculata adalah total tinggi 1134 $\mathrm{cm}$, total daun 24 helai daun, total cabang 34, pada jenis Rhizophora mucronata total tinggi $350 \mathrm{~cm}$, total daun 38 , total cabang 8 , pada jenis Brugueira Gymnoriza total tinggi $898 \mathrm{~cm}$, total daun 128 helai daun, total cabang 38, dan pada jenis Sonneratia albatotal tinggi $263 \mathrm{~cm}$, total daun 48 helai dan total cabang 4 . Bila melihat data ditahun 2019 total tinggi Rhizophora apiculata $459 \mathrm{~cm}$, total daun 101 helai daun, total cabang hanya 2, pada jenis Rhizophora mucronata total tinggi $293 \mathrm{~cm}$, total daun 41, total cabang 2, pada jenis Brugueira gymnoriza total tinggi $730 \mathrm{~cm}$, total daun 322 helai daun, total cabang 16, dan pada jenis Sonneratia alba total tinggi $176 \mathrm{~cm}$, total daun 35 helai dan total cabang 0 . 


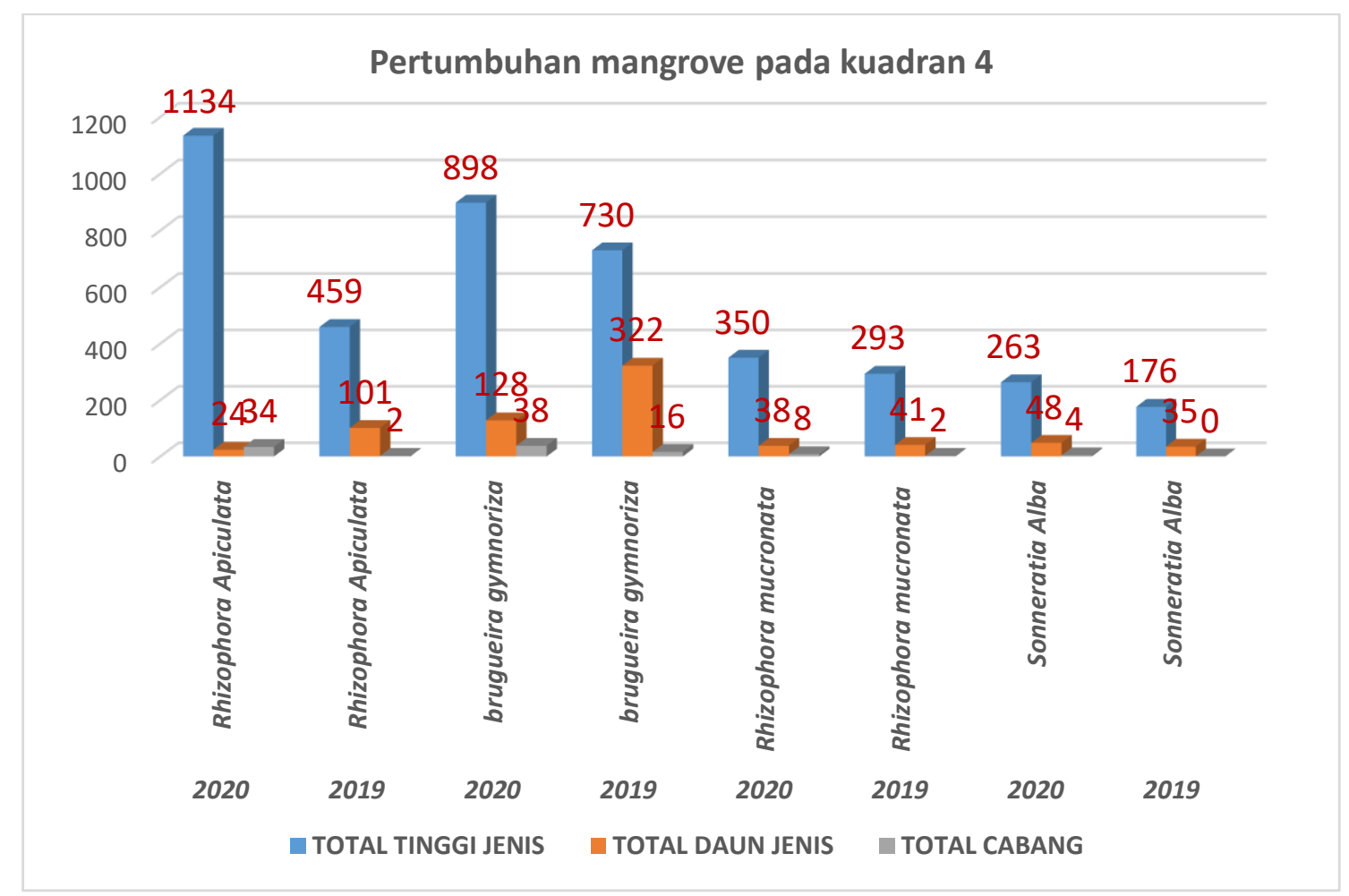

Gambar 14. Total Pertumbuhan Mangrove Pada Kuadran 4

Pada kuadran empat di dapatkan ratarata pertumbuhan mangrove (Gambar 14) pada mangrove jenis Rhizophora apiculata rata-rata tinggi adalah $141,75 \mathrm{~cm}$, rata-rata daun 3 helai daun, rata-rata cabang 4,25, pada jenis Rhizophora mucronata rata-rata tinggi $87,50 \mathrm{~cm}$, rata-rata daun 9,5 helai daun, ratarata cabang 2, pada jenis Brugueira gymnoriza rata-rata tinggi $74,83 \mathrm{~cm}$, rata-rata daun 10,67 helai daun, rata-rata cabang 3,17 , dan pada jenis Sonneratia alba rata-rata tinggi $43,83 \mathrm{~cm}$, rata-rata daun 8 helai dauan dan rata-rata cabang 0,67. Bila melihat data ditahun 2019 rata-rata tinggi Rhizophora apiculata $57,37 \mathrm{~cm}$, rata-rata daun 12.62 helai daun, rata-rata cabang hanya 0,25 , pada jenis Rhizophora mucronata rata-rata tinggi $73,25 \mathrm{~cm}$, rata-rata daun 10,25 helai daun, rata-rata cabang 0,5 , pada jenis Brugueira gymnoriza rata-rata tinggi $60,83 \mathrm{~cm}$, rata-rata daun 26,83 helai daun, rata-rata cabang 1,33 , dan pada jenis Sonneratia alba rata-rata tinggi $29,33 \mathrm{~cm}$, ratarata daun 5,83 helai daun dan rata-rata cabang 0 . 


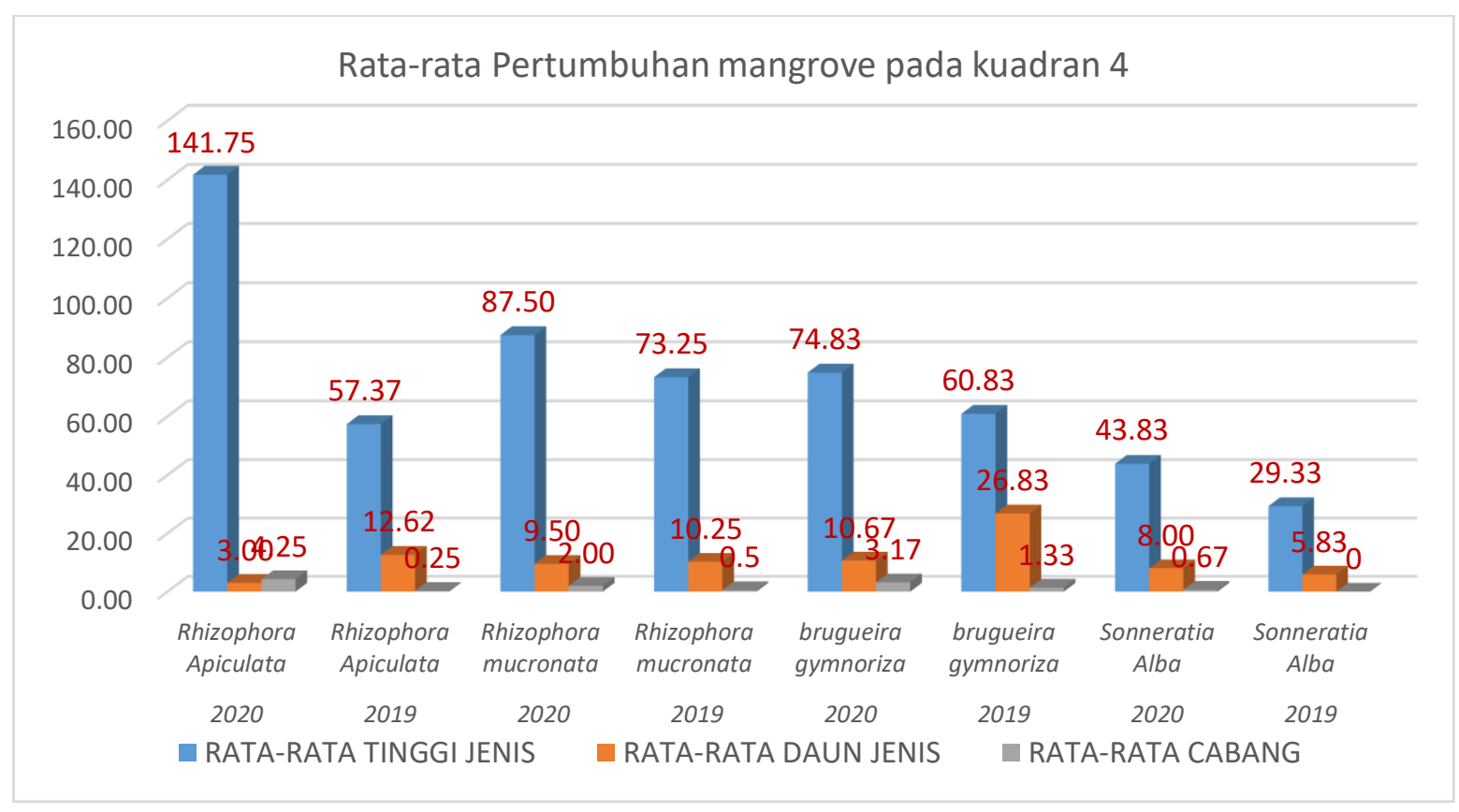

Gambar 15. Rata-rata Pertumbuhan Mangrove Pada Kuadran 4

Dari hasil penelitian didapatkan bahwa terjadinya pertumbuhan yang cukup signifikan pada tinggi dan cabang mangrove yang di tanam pada modul mangrove park yang ada di kampus Ekowisata Bawah Luat Tateli, namun adidapatkan adamya penurunan jumlah daun di beberapa individu mangrove, karena mengalami fase gugur. Berdasarkan hasil penelitian yang dilakukan, maka dapat disimpulkan bahwa: laju pertumbuhan karang Acropora dan Policopora pada modul Polimdo dan Kotak, menunjukkan adanya peningkatan yang cukup baik. Rata-rata pada media mengalami pertumbuhan sejak dilakukannya transplantasi pada bulan September 2019 sampai Juni 2020. Dari data yang diperoleh pada bulan Juni 2020 , pertambahan panjang karang yang di modul Polimdo selama 10 bulan mengalami pertumbuhan $1,09 \mathrm{~cm} /$ bulan. Hal yang sama juga pada modul kotak mengalami pertumbuhan karang 0,57 $\mathrm{cm} /$ bulan

\section{KESIMPULAN:}

Kondisi ekologi dan oseanografi ekosistem mangrove adalah suhu, salinitas, $\mathrm{PH}$, kedalaman dan kecerhan sangat baik untuk kesesuaian lahan ekosistem mangrove dan terumbu karang sebagai laboratorium alam karena hasil pengukuran menunjukkan angka yang masih masuk dalambatas baku mutu sesuai dengan Baku Mutu Kepmen LH No. 51 Tahun 2004.

Data perkembangan ekosistem terumbu karang dan mangrove, keduanya berdasarkan hasil penelitian yang dilakukan, maka dapat disimpulkan bahwa: laju pertumbuhan karang Acropora dan Policopora pada modul Polimdo dan Kotak, menunjukkan adanya peningkatan yang cukup baik. Rata-rata pada media mengalami pertumbuhan sejak dilakukannya transplantasi pada bulan September 2019 sampai Juni 2020. Dari data yang diperoleh pada bulan Juni 2020, pertambahan panjang karang yang di modul Polimdo selama 10 bulan mengalami pertumbuhan $1,09 \mathrm{~cm} /$ bulan. Hal yang sama juga pada modul kotak mengalami pertumbuhan karang $0,57 \mathrm{~cm} /$ bulan. Sedangkan untuk mangrove terjadinya pertumbuhan yang signifikan pada tinggi dan cabang mangrove yang di tanam pada modul mangrove park yang ada di kampus Ekowisata Bawah Luat Tateli di epat kuadran yang ada. kemudian teridentifikasi ada 4 jenis mangrove yaitu Rhizophora apiculata, Rhizophora mucronata, Sonnertaia alba dan Bruguiera gymnorhiza

Dari data mangrove dan terumbu karang di area mangrove dan terumbu karang buatan dalam pertumbuhan yang signifikan maka 
sanagat berpotensi untuk dijadikan sebagai sarana edukasi dalam hal ini lanoratorium alam yang berguna untuk mahasiswa dalam

\section{DAFTAR PUSTAKA}

Anonimus, 1990. Pembangunan aspek, kelautan dalam pembangunan jangka panjang 25 tahun kedua. Rumusan hasil diskusi tanggal 31 Januari 1990 di Jakarta. TNI - AL

Bengen, D. G. 2001. Pengenalan dan Pengelolaan Ekosistem Mangrove. Pusat Kajian Sumberdaya Pesisir dan Lautan. IPB. Bogor.

Barlia, Lily. 2006. Mengajar dengan Pendekatan Lingkungan Alam Sekitar. Jakarta: Depdiknas.

Bohnsack, J.A. and D.L. Sutherland 1985. Artificial reef research : a review with recommendation for future priorities. Bull. Mar. Sci 37 (1) : 11 - 39. 32 www.oseanografi.lipi.go.id Oseana, Volume XVI No. 1, 1991

Carin, Arthur A \& Sund, Robert B. 1980. Teaching Modern Science. Ohio: Bell \& Howell Company.

Chou, I.m. and A.T. White, 1987. Artificial habitats. In : T.E. Chua, L.M. Chou and M.SM Sadorra (eds). The coastal environmental profile of Brunei Darussalam resource assessment and management issues. International Center for Living Aquatic Resources Management, Manila. Phillipines. 60-63.

De Silva M.W.R.N. 1989. Artificial reef : a practical means to enhance living marine resources. In : T.E. CHUA and D. PAULY (eds). Coastal area management in Southeast Asia : Policies, Management, Dtrategies and Case Studies ; 173-180. pembelajaran juga untuk dosen dalam pengembangan penelitian.

Joyce, B.\& Weil, M. 1996. Models of Teaching 5th Ed. London: Allyn and Bacon. Majid, Abdul. 2014. Pembelajaran Tematik Terpadu. Bandung: Remaja Rosdakarya.

Soerianegara, I. dan A. Indrawan. 1985. Ekologi Hutan Indonesia. Departemen Manajemen Hutan Fakultas Kehutanan IPB. Bogor.

Supriharyono. 2000. Pelestarian dan Pengelolaan Sumberdaya Alam di Wilayah Pesisir Tropis. PT. Gramedia Pustaka Utama. Jakarta.

Suwelo, I.S. 1993. Jenis - Jenis Burung di Jakarta Ditinjau dari Segi Ekologi. Makalah Seminar Sehari "Burung dan Upaya Pelestariannya", KPB Symbiose FMIPA Biologi UI. Jakarta. 